УДК 330.33.01:336

\title{
ВПЛИВ ФІНАНСОВО-ЕКОНОМІЧНОЇ КРИЗИ НА ДОХОДИ ТА ВИТРАТИ НАСЕЛЕННЯ УКРАЇНИ
}

\author{
Богоявленський О.В., к.е.н., доцент, \\ Ворфоломєєва М.О., студент (ХІФУДУФМТ)
}

\begin{abstract}
У статті досліджено напрями впливу фінансово-економічної кризи на доходи та витрати населення України. За статистичними даними проаналізовано рівень, динаміку доходів та витрат громадян. Порівняно забезпеченість населення України із іншими крайнами світу. Також обтрунтовано негативні наслідки кризового стану країни, що безпосередньо виливає на дохідність населення. Запропоновано основні шляхи подолання фінансовоекономічної кризи.
\end{abstract}

Ключові слова: фінансово-економічна криза, доходи, витрати, економічний стан, споживання, рівень життя, інфляція, заборгованість, купівельна спроможність.

\section{ВЛИЯНИЕ ФИНАНСОВО-ЭКОНОМИЧЕСКОГО КРИЗИСА НА ДОХОДЫ И РАСХОДЫ НАСЕЛЕНИЯ УКРАИНЫ}

\author{
Богоявленский О.В., к.э.н., доцент, \\ Ворфоломеева М.А., студент (ХИФУГУФМТ)
}

В статье исследованы направления влияния финансово-экономического кризиса на доходы и расходы населения Украины. По статистическим данным проанализирован уровень, динамику доходов и расходов граждан. По сравнению обеспеченность населения Украины с другими странами мира. Также обоснованно негативные последствия кризисного состояния страны, непосредственно влияет на доходность населения. Предложены основные пути преодоления финансово-экономического кризиса.

Ключевые слова: финансово-экономический кризис, доходы, расходы, экономическое положение, потребление, уровень жизни, инфляция, задолженность, покупательная способность.

\section{IMPACT OF THE FINANCIAL CRISIS ON HOUSEHOLD INCOME AND EXPENDITURE UKRAINE}

\author{
Bogoyavlensky O.V., Candidate of Economic Sciences, associate professor, \\ Vorfolomyeyeva M.O., student (KIFUSUFIT)
}

The article shows the concept of financial crisis and analyzes the impact of the crisis on the economy in general. Directions impact of financial crisis on income and expenditure of Ukraine. According to statistical data analysis level, the dynamics of income and expenses citizens. And also given work studied their composition and structure. Compared supply to the population of Ukraine with other countries. Also proved negative effects of the crisis situation of the country, which directly affects the yield of the population. In the article the basic ways of overcoming the financial and economic crisis by pokarschennya welfare of the population and its purchasing power.

Key words: financial crisis, revenues, costs, economic status, consumption, standard of living, inflation, debt, purchasing capacity. 
Постановка проблеми. Кожна країна прагне економічної стабільності, припинення спаду виробництва та зростання ефективності господарської діяльності. Проте ринкова економіка має циклічний характер, що періодично призводить до криз. У сучасний період часу розвитку економіки України населення відіграє важливу роль як споживач товарів та послуг. Несталість економіки країни згубно позначається на рівні добробуту громадян. Фінансові та економічні кризи негативно відгукаються у вигляді інфляцій цін, безробіття, зменшення доходів та зниження купівельної спроможності населення. Все це від'ємно впливає на усі складові економічної системи країни. В свою чергу, це відб'ється на тих підприємствах, виробництво яких орієнтоване на внутрішній ринок. Таким чином, проблема підвищення життєвого рівня населення $\epsilon$ різноплановою, актуальною i прямо пов'язана 3 виведенням національної економіки з кризового стану.

Аналіз останніх

досягнень i

публікацій. Питання макроекономічних циклів і періодичність фінансово-економічних криз та їх від'ємна дія на ринкову економіку країни, а також становище населення постійно знаходиться в полі зору науковців. Розглядаючи цю проблему, можна опиратися на дослідження таких вчених, як Arsenio M. Balisacan [1], Josef T. Yap [2], Malindi Myers [3], Sheria Myrie [4], C.I. Бандур [5], І.Г. Лук'яненко [6] та багато інших. Роботи цих науковців безпосередньо стосуються питання про негативний вплив кризи на рівень життя населення, зниження споживання, заборгованість за заробітною платою. Також приділяється увага соціальноекономічним наслідкам кризи.

Виділення невирішених раніше частин загальної проблеми. Проблема впливу фінансово-економічної кризи $є$ актуальною на сьогоднішній день. Велика кількість науковцівекономістів працюють над вирішенням цього питання. Увага концентрується на причинах зниження рівня життя українців та падіння їх купівельної спроможності, а також нерівномірному розподілі доходів між верствами населення. Отже, першочерговим планом постає необхідність подолання кризи, що є наслідком від'ємного впливу на соціальноекономічний рівень забезпеченості громадян.

Метою статті $є$ дослідження напрямів впливу фінансово-економічної кризи на доходи та витрати населення України, обгрунтування іiі негативних наслідків, а також запропонувати основні шляхи їх вирішення.

\section{Виклад основного матеріалу}

дослідження. Фінансово-економічна криза - це явище, під час якого відбувається розлад господарської системи та супроводжується значними втратами й розривом нормальних зв'язків у виробництві й ринкових відносинах, а також виводить із нормального стану функціонування економічної системи в цілому. Вплив економічної кризи на споживчу модель поведінки українського населення сьогодні $\epsilon$ дуже актуальною, бо на сучасному етапі Україна потерпає від неї. Тяжке становище від проявів кризи супроводжується відносним надвиробництвом через обмеження платоспроможного попиту населення, що $\epsilon$ результатом збіднінням робітничих мас. Для подолання кризи необхідне встановлення рівноваги між виробництвом та споживанням, що спричинить суспільні трансформації всіх структур народного господарства, створення нових правил і принципів поведінки суб'єктів ринку, пріоритетного розвитку інтересів споживачів.

Кризове становище в Україні має свої особливості. В останні роки прослідковується збільшення кризових явищ, інфляція розповсюджується на всю систему кредитної, фінансової i банківської діяльності, зменшується ділова активність, зростає міграція робочої сили у країни близького й далекого зарубіжжя, підвищується частка тіньової економіки. Криза має системний характер, охоплює всі сфери життя суспільства економічну, політичну й соціальну. Процес трансформації кон'юктури ринку в Україні проходить у несприятливих умовах: відбувається розрив економічних зв'язків між галузями, підприємствами, містами і людьми; простежується спекулятивне підвищення цін державою; стрімке зниження життєвого рівня більшої частини населення країни; спад виробництва ВВП та ін.

Враховуючи також тяжкі обставини на сході України починаючи 32014 року, економіка країни та соціальний добробут значно потребують допомоги. Антитерористичні акти, що мають місце на території України, потребують значних коштів 3 бюджету, яких i так недостатньо. Значна частка доходів країни приділяється на оборону, озброєння армії та соціальні виплати сім'ям постраждалих. А найголовнішою втратою $\epsilon$ 
людські життя. Все це перешкоджає виходу 3 стабільні темпи зростання цих показників із кризи i робить іiі ще більш затяжною i 2009 по 2015 рік, що говорить про сприятливе глибокою, створює нестабільне економічне становище в країні (табл. 1). Проте середовище, зменшує доходи населення, розглянувши більш детально джерела вимушує його бути не купівельно спроможним. формування доходів та напрями їх витрачання Аналізуючи доходи, витрати та прослідковуються негативні явища.

заощадження населення взагалі спостерігаємо

Таблиия 1

Динаміка доходів та витрат населення Украӥни за 2009 - 2015роки, млн. грн.

\begin{tabular}{|c|c|c|c|c|c|c|c|}
\hline & 2009 & 2010 & 2011 & 2012 & 2013 & 2014 & 2015 \\
\hline ДОХОДИ & 218312 & 255633 & 303623 & 345492 & 362511 & 385347 & 406858 \\
\hline заробітна плата & 92816 & 108340 & 131059 & 144831 & 152383 & 157059 & 167487 \\
\hline $\begin{array}{l}\text { прибуток та змішаний } \\
\text { дохід }\end{array}$ & 26862 & 31550 & 40934 & 44688 & 47506 & 54482 & 60987 \\
\hline $\begin{array}{l}\text { доходи від власності } \\
\text { (одержані) }\end{array}$ & 7653 & 8642 & 12990 & 17240 & 17332 & 21977 & 19032 \\
\hline $\begin{array}{l}\text { соціальні допомоги та } \\
\text { інші одержані поточні } \\
\text { трансферти }\end{array}$ & 90981 & 107101 & 118640 & 138733 & 145290 & 151829 & 159352 \\
\hline \multicolumn{8}{|l|}{ у тому числі: } \\
\hline соціальні допомоги & 50390 & 61573 & 67345 & 76670 & 80672 & 83231 & 80834 \\
\hline $\begin{array}{l}\text { інші поточні } \\
\text { трансферти }\end{array}$ & 7753 & 7579 & 8087 & 10041 & 10148 & 14150 & 18508 \\
\hline $\begin{array}{l}\text { соціальні трансферти } \\
\text { в натурі }\end{array}$ & 32838 & 37949 & 43208 & 52022 & 54470 & 54448 & 60010 \\
\hline $\begin{array}{l}\text { ВИТРАТИ ТА } \\
\text { ЗАОЩАДЖЕННЯ }\end{array}$ & 218312 & 255633 & 303623 & 345492 & 362511 & 385347 & 406858 \\
\hline $\begin{array}{l}\text { придбання товарів та } \\
\text { послуг }\end{array}$ & 172313 & 196943 & 248734 & 289711 & 316552 & 330552 & 362950 \\
\hline $\begin{array}{l}\text { доходи від власності } \\
\text { (сплачені) }\end{array}$ & 9170 & 6913 & 6550 & 7139 & 7610 & 6887 & 6972 \\
\hline $\begin{array}{l}\text { поточні податки на } \\
\text { доходи, майно та інші } \\
\text { сплачені поточні } \\
\text { трансферти }\end{array}$ & 16490 & 18737 & 21849 & 24185 & 26086 & 27063 & 34557 \\
\hline \multicolumn{8}{|l|}{ у тому числі: } \\
\hline $\begin{array}{l}\text { поточні податки на } \\
\text { доходи, майно тощо }\end{array}$ & 11555 & 12760 & 15141 & 17178 & 18156 & 18138 & 24419 \\
\hline $\begin{array}{l}\text { внески на соціальне } \\
\text { страхування }\end{array}$ & 2879 & 3534 & 4091 & 4001 & 3837 & 4149 & 3946 \\
\hline $\begin{array}{l}\text { інші поточні } \\
\text { трансферти }\end{array}$ & 2056 & 2443 & 2617 & 3006 & 4093 & 4776 & 6192 \\
\hline $\begin{array}{l}\text { нагромадження нефін } \\
\text { ансових активів }\end{array}$ & -814 & 1222 & -242 & -525 & 1991 & -1652 & -5361 \\
\hline $\begin{array}{l}\text { приріст фінансових } \\
\text { активів }\end{array}$ & 21153 & 31818 & 26732 & 24982 & 10272 & 22497 & 7740 \\
\hline \multicolumn{8}{|l|}{3 них: } \\
\hline $\begin{array}{l}\text { приріст грошових } \\
\text { вкладів та } \\
\text { заощаджень в цінних } \\
\text { паперах }\end{array}$ & 12851 & 33132 & 17033 & 21236 & 33764 & 17957 & -42702 \\
\hline $\begin{array}{l}\text { позики, одержані за } \\
\text { виключенням } \\
\text { погашених (-) }\end{array}$ & -13477 & -8010 & 884 & -5096 & 1596 & -2256 & -46118 \\
\hline
\end{tabular}

Вісник економіки транспорту і промисловості № 52, 2015 
За результатами 2015 року із загальних доходів, що складають 406858 млн. грн., населення витрачає на придбання товарів та послуг 362950 млн. грн. Цей показник збільшився на 32398 млн. (3\%) грн. у порівнянні із минулим роком. Натомість витрати на поточні податки на доходи та майно, що склали у 2014 році 27063 млн. грн. також зросли у 2015 році до 34557 млн. грн. [7].

Криза, в якій потерпає наша країна, вплинула на витрати на приріст грошових вкладів та заощаджень в цінних паперах, що у 2015 році мають від'ємний показник, а також і на витрати на заощадження в іноземній валюті - починаючи із 2013 року і дотепер із знаком «мінус». Це говорить про нестачу у громадян вільних коштів, а також про їх недовіру до фінансових структур, що негативно впливає на ринкову економіку країни.

Наведені вище факти стали наслідком стрімкого падіння курсу гривні через відсутність ефективної державної підтримки фінансового сектора, корпоративного боргу та високих темпів інфляції. Висока ставка національного банка України різко збільшує вартість всіх кредитів. Майже більша частина населення, малий та середній бізнес можуть бути відрізані від кредитів. Іпотека, автомобільний кредит, споживчі кредити стали менше використовуватися на сучасному етапі.

Згідно 3 даними НБУ, динаміка депозитів 3 початку року залишається негативною. Гривневі депозити в січні-серпні знизилися на 2,9\%, валютні - на $23,4 \%$. Залишки за гривневими кредитами в серпні зросли на $1,1 \%$, 3 початку року скоротилися на 9,7\% - до 490200000000 грн. Залишки за валютними кредитами в серпні знизилися на $0,9 \%, з$ початку року - знизилися на $14,7 \%$ - до 25,6 млрд. дол. [8]. Це початок рушійної сили різкого зниження споживання товарів довгострокового споживання, а також житла, автомобілів, крупної побутової техніки.

За 2009 - 2015 роки мінімальна заробітна плата мала тенденцію вгору від 744 грн. до 1218 грн. за місяць (рис. 1). Проте останні три роки цей показник мав незмінне значення. Простежується негативний вплив кризового стану країни, оскільки, мінімальна заробітна плата залишалася у тому самому значенні порівнюючи 3 тим, що податки на доходи та майно зростали: при однаковому рівні доходів 32013 по 2015 роки (1218 грн.) населення витрачало на податки кожного року все більше коштів, що зменшувало їх купівельну спроможність.

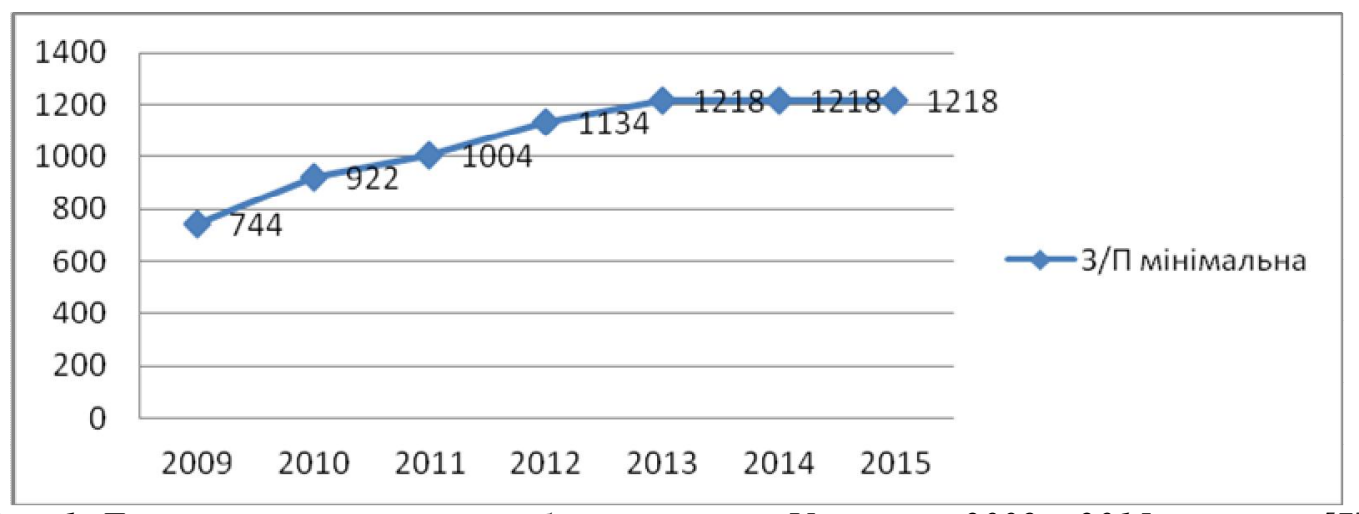

Рис. 1. Динаміка мінімальної заробітної плати в Україні за 2009 - 2015 роки, грн.[7]

Значною залишається заборгованість виплати заробітної плати (рис. 2). Найбільше збільшення цього показника спостерігається в період загострення економічної ситуації в країні.

Так у 2015 році він зріс до 1963,8 млн. грн. У 2012 році заборгованість становила 915,9 млн. грн., на 1047,9 млн. грн. менше, ніж у поточному році.

Така ситуація змушує населення скорочувати свої витрати, переходити на більш дешеві товари та послуги, шукати товаро-замінники, навіть відмовлятися від повсякденних витрат.

Кількість пенсіонерів в Україні за 2009-2015 роки зменшилася від 13749 тис. чол. до 13533 тис. чол., а розмір середньої місячної пенсії навпаки збільшився від 943,7 грн. до 1573 грн. (табл. 2). Проте не слід забувати про таке негативне явище, як інфляція, що «з'їдає» велику частку доходу.

Вісник економіки транспорту і промисловості № 52, 2015 


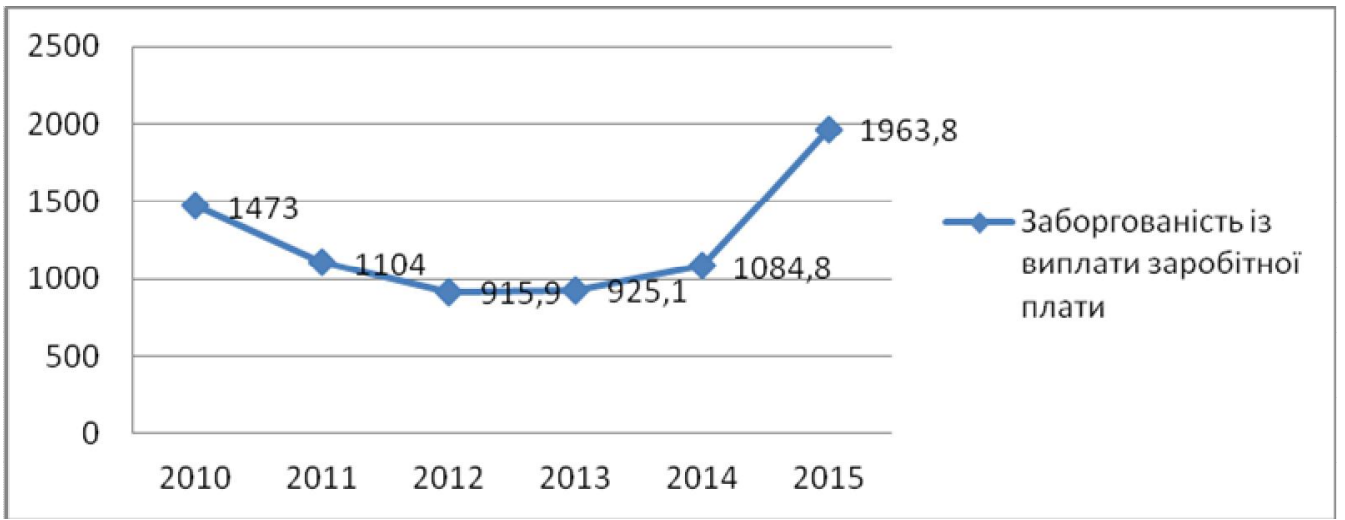

Рис. 2. Заборгованість із виплати заробітної плати в Україні за 2010 - 2015 роки, млн. грн. [7]

Таблиия 2

Середній розмір місячної пенсії та кількість пенсіонерів в Україні за 2009-2015 роки

\begin{tabular}{|c|c|c|c|c|}
\hline \multirow[t]{3}{*}{ Роки } & \multirow[t]{3}{*}{$\begin{array}{l}\text { Кількість } \\
\text { пенсіонерів, } \\
\text { тис.чол. }\end{array}$} & \multicolumn{3}{|c|}{$\begin{array}{c}\text { Середній розмір призначеної місячної пенсії } \\
\text { пенсіонерам, які перебувають на обліку в органах } \\
\text { Пенсійного фонду, грн. }\end{array}$} \\
\hline & & \multicolumn{3}{|c|}{ у тому числі: } \\
\hline & & за віком & $\begin{array}{c}\text { за } \\
\text { інвалідністю }\end{array}$ & $\begin{array}{r}\text { у разі } \\
\text { втрати } \\
\text { годувальника }\end{array}$ \\
\hline 2009 & 13749,8 & 942,7 & 1573,0 & 696,6 \\
\hline 2010 & 13721,1 & 1039,6 & 884,6 & 807,9 \\
\hline 2011 & 13738,0 & 1156,0 & 1033,8 & 940,0 \\
\hline 2012 & 13820,5 & 1252,4 & 1164,3 & 1053,8 \\
\hline 2013 & 13639,7 & 1464,3 & 1359,2 & 1252,8 \\
\hline 2014 & 13533,3 & 1521,6 & 1406,5 & 1303,8 \\
\hline 2015 & 13533,3 & 1573,0 & 1432,1 & 1433,1 \\
\hline
\end{tabular}

Одним із від'ємних проявів фінансовоекономічної кризи є інфляція. Основними негативними наслідками інфляції $є$ падіння рівня життя населення. Найбільше страждають групи населення 3 фіксованим доходом - наприклад, особи, що отримують заробітну плату або ж соціальну допомогу від держави. Відбувається також погіршення очікувань щодо макроекономічної ситуації в майбутньому, що приводить, зокрема, до зниження ділової активності.

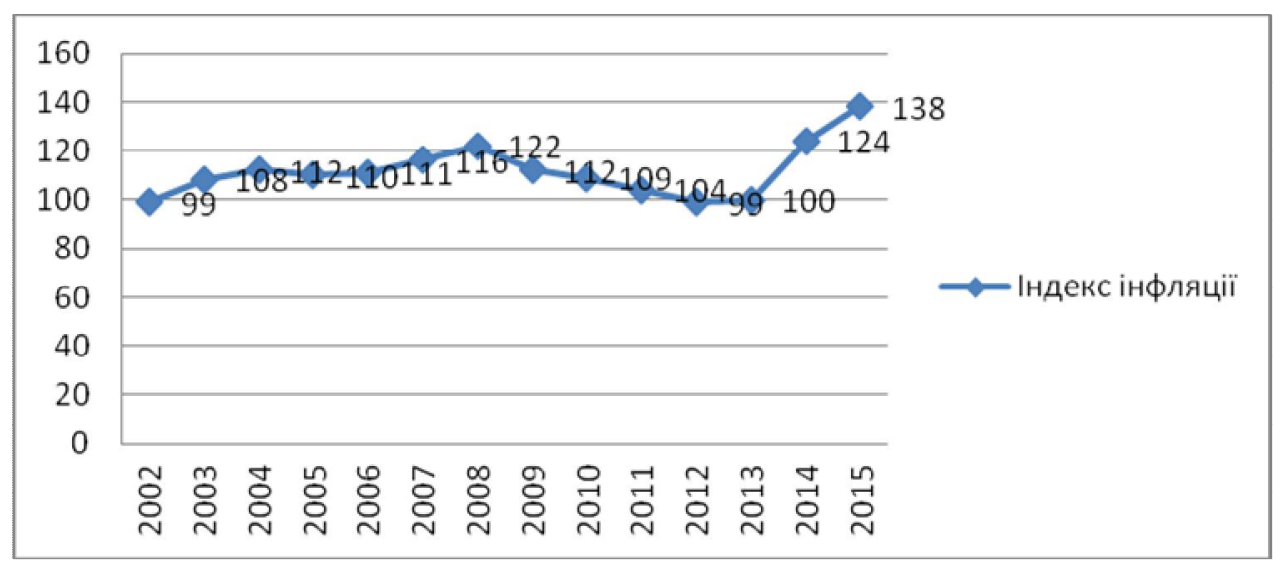

Рис. 3. Індекс інфляиії України за 2002 - 2015 роки у відсотках[7] 
Прослідковуючи динаміку індексу інфляції за 2002 - 2015 роки, бачимо, що тільки у 2003 та 2012 роках рівень інфляції мав від'ємний показник. За період 2008 - 2012 інфляція мала тенденцію зниження від $12 \%$ до $-1 \%$. Проте під час економічної кризи цей показник стрімко пішов вгору. Вже у 2014 році рівень інфляції дорівнював $24 \%$, а у цьому році взагалі досяг $38 \%$. Тільки за один нестабільний рік в Україні цей показник зріс на $14 \%$ (рис. 3). Тобто, на сучасному періоді із 1218 грн. мінімальної заробітної платні (рис. 1) або 1573 грн. середньої місячної пенсії (табл.2) громадянин України отримає, за вирахуванням інфляції, що складає у 2015 році 38\%, 755,16 грн. або 975,26 грн. відповідно реальних доходів.

Сучасна фінансово-економічна криза відображає свій прояв на витратах населення. Це явище прослідковується у розрізі споживчих сукупних витратах. На прикладі харківської області простежується їх зменшення від 93,1\% у 2011 році до 91\% у 2015 році (табл. 3). За структурою сукупних витрат по харківській області висвітлюється, що громадяни України стали менше витрачати кошти на продукти харчування та безалкогольні напої (зменшилися від 51,4\% у 2009 році до 48,6\% у 2015), на алкогольні напої та тютюнові вироби (сповзли вниз від $3,8 \%$ до $3,3 \%$ ). На споживчих ранках значно збільшились ціни на молочні вироби,кондитерські, консервних галузей, оскільки ці позиції за допомогою Росії були майже обмежені в експортних можливостях. Прикладом такої ситуації $є$ подорожчання вершкового масла на 8,7 грн., кілограм м'якого сира на 7,9 грн. Найбільший ріст цін за рік продемонстрували такі соціально значущі продукти, як цукор (збільшився на $66 \%$ ), м'ясо птиці (зросло на 33\%) та свинина (підвищилася на 27\%). Структура споживчої корзини у 2015-2016 роках буде змінюватися в першу чергу за рахунок послаблення курсу гривні до іноземної валюти та подорожчання імпортних продуктів харчування,таких як риба, фрукти, чай, кофе та інші [9].

Таблиия 3

Структура сукупних витрат по харківській області за 2009-2014 роки

\begin{tabular}{|c|c|c|c|c|c|c|}
\hline & 2009 & 2010 & 2011 & 2012 & 2013 & 2014 \\
\hline 1 & 2 & 3 & 4 & 5 & 6 & 7 \\
\hline $\begin{array}{lcr}\text { Сукупні } & \text { витрати } & \text { в } \\
\text { середньому } & \text { за місяць } \\
\text { розрахунку } & \text { на одне } \\
\text { домогосподарство, грн. } & \end{array}$ & 2549,9 & 2892,6 & 3136,4 & 3333,8 & 3682,2 & 4014,8 \\
\hline $\begin{array}{l}\text { Структура сукупних витрат } \\
\text { домогосподарств }\end{array}$ & \multicolumn{6}{|c|}{ відсотків } \\
\hline Споживчі сукупні витрати & 92,1 & 93,0 & 93,1 & 92,9 & 92,5 & 91,0 \\
\hline $\begin{array}{l}\text { продукти харчування та } \\
\text { безалкогольні напої }\end{array}$ & 51,4 & 50,7 & 50,2 & 48,2 & 47,5 & 48,6 \\
\hline $\begin{array}{l}\text { алкогольні напої, тютюнові } \\
\text { вироби }\end{array}$ & 3,8 & 3,7 & 3,7 & 3,8 & 3,8 & 3,3 \\
\hline $\begin{array}{llc}\text { непродовольчі } \\
\text { послуги }\end{array}$ & 36,9 & 38,6 & 39,2 & 40,9 & 41,2 & 39,1 \\
\hline \multicolumn{7}{|l|}{ в тому числі } \\
\hline одяг і взуття & 6,2 & 6,7 & 6,7 & 6,5 & 6,8 & 6,7 \\
\hline $\begin{array}{l}\text { житло, вода, електроенергія, } \\
\text { газ та інші види палива }\end{array}$ & 11,2 & 11,1 & 11,4 & 12,3 & 11,3 & 10,9 \\
\hline $\begin{array}{l}\text { предмети домашнього } \\
\text { вжитку, побутова техніка та } \\
\text { поточне утримання житла }\end{array}$ & 2,4 & 3,0 & 2,7 & 2,9 & 2,9 & 2,7 \\
\hline охорона здоров'я & 2,7 & 2,7 & 2,7 & 2,9 & 2,7 & 3,0 \\
\hline транспорт & 4,3 & 4,4 & 4,5 & 4,4 & 5,3 & 5,3 \\
\hline зв'язок & 2,6 & 3,0 & 2,9 & 3,2 & 3,4 & 3,2 \\
\hline
\end{tabular}

Вісник економіки транспорту і промисловості № 52, 2015 
Продовження табл.3

\begin{tabular}{|l|c|c|c|c|c|c|}
\hline 1 & 2 & 3 & 4 & 5 & 6 & 7 \\
\hline відпочинок і культура & 2,2 & 1,8 & 2,1 & 2,1 & 2,1 & 1,6 \\
\hline освіта & 0,8 & 0,9 & 1,0 & 1,2 & 1,1 & 0,6 \\
\hline ресторани та готелі & 2,3 & 2,8 & 2,7 & 2,8 & 2,9 & 2,3 \\
\hline різні товари та послуги & 2,2 & 2,2 & 2,5 & 2,6 & 2,7 & 2,8 \\
\hline Неспоживчі сукупні витрати & 7,9 & 7,0 & 6,9 & 7,1 & 7,5 & 9,0 \\
\hline $\begin{array}{l}\text { Додатково: оплата житла, } \\
\text { комунальних продуктів та } \\
\text { послуг }\end{array}$ & 10,3 & 10,0 & 10,1 & 11,2 & 10,3 & 10,0 \\
\hline
\end{tabular}

Дослідження структури сукупних витрат доводить, що українці витрачають майже половину своїх доходів на продукти харчування, натомість середня американська статистична сім'я - тільки $10 \%$, німецька $12 \%$, французька - $15,9 \%$ сімейного бюджету. Проте така ситуація не говорить, що українська нація значно забезпечена та живе у достатку. У більш заможних країнах частка витрат на продукти харчування значно менша, ніж у бідних. Поясненням такого становища $\epsilon$ підвищення економічного зростання країни, внаслідок чого зростають і доходи споживачів значно швидше, у порівнянні із цінами на продовольчі та непродовольчі товари. Отже, більша частка коштів домогосподарств залишається на інші цілі.

Факторами впливу на таку вагому відмінність між витратами різних країн на продукти харчування $\epsilon$ несхожість у системах оподаткування, у культурі харчування. Також вагомим $\epsilon$ те, що, наприклад, у США сільське господарство активно субсидується, що сприяє падінню цін на кінцевому ринку. В Україні сільське господарство піклується про себе самостійно, що змушує продавців піднімати ціни на продукцію. Українське населення витрачає кошти на живлення поза домашніх умов, на кафе, ресторани $2,3 \%$ своїх доходів у порівнянні з тим, що витрати на продукти харчування складають $48,6 \%$. Натомість, наприклад, у Люксембурзі - 7,4\%, у Великобританії - більше $10 \%$. Таке становище супроводжується бідністю населення та відмінністю культури харчування із іншими країнами: українці більш байдужі до живлення у суспільних місцях. Непродовольчі товари та послуги, що склали у 2015 році $39,1 \%$ від всіх споживчих сукупних витрат, також мали тенденцію до зниження. До таких товарів відносять: предмети особистої гігієни, побутова хімія, косметика. За цією продукцією спостерігається скорочення попиту та економія споживачів за нею. Це відбувається через те, що вагома кількість непродовольчих товарів має імпортну складову у своїй ціні, тому їх вартість збільшилася пропорційно девальвації гривні. Отже, більшим попитом користуються вітчизняні виробники та аукціонні пропозиції.

За статистичними даними відображено збільшення показника транспортного засобу за останні два роки до 5,3\% сукупних витрат населення України. Це свідчення набагато менше у зіставленні із європейськими країнами, що складає у середньому $15 \%$ від усіх витрат, проте не варто забувати, що середня кількість автомобілів у Свропі вища, ніж в України. В умовах невизначеності для середньостатистичних українських сімей це ще один засіб зекономити. За рахунок подорожчання горючого, обслуговування особистих автомобілів кількість користувачів суспільним українським транспортом зросла. Незважаючи на збільшення вартості проїзду в автотранспорті, українці будуть вірні цьому засобу пересування.

Ще одним позитивним явищем для українського населення є зменшення витрат на комунальні послуги від $12,3 \%$ у 2013 році до $10,9 \%$ у 2015 році. Різниця у структурі витрат на ці послуги також простежується між Європою та Україною. На відміну від українців, європейці сплачують за комунальні послуги у середньому $20-30 \%$ сукупних витрат.

2015 рік видався складним: харківчани стали менше витрачати коштів на розваги та відпочинок, що склали 1,6\% загальних витрат, натомість австрійці витрачають - $12 \%$ бюджету домогосподарства. В українських концертних агентствах в оренду переважно беруться невеликі зали місткістю до 1 тис. 
чол., оскільки оренда великих концертних майданчиків окупається у частині випадків залежачи від програми. Відмічають спад попиту i в торгово-розважальних центрах. Деяким винятком цього сегменту стали кінозали, тому що цей вид розваги став одним i3 найбільш доступних. Окрім цього більша частина українців відмовилася від відпочинку. Туристичні агентства максимально знижують ціни, але у зв'язку з девальвацією гривні вони все одно залишаються недосяжними для громадян України. За даними наведеної таблиці спостерігається збільшення витрат на охорону здоров'я. Цей фактор свідчить про збільшення вартості медичних препаратів, а також - на медичне обслуговування.

Витрачання на освіту - одна 3 найважливіших ознак соціального розвитку, тому що показує ступінь уваги, що зосереджує держава та суспільство на створення громадян. Інвестування в освіту дозволяє країні збільшити людський капітал, а також покращити перспективи економічного зростання. У свою чергу освіта має і власну цінність: розширює світогляд людей, забезпечує можливість до самореалізації, сприяє їх матеріальному благополуччю та здорового способу життя. В Україні показник витрат коштів на освіту зменшився у 2015 році до $0,6 \%$ сукупних витрат домогосподарств, що вказує на нестачу коштів у населення. За рейтингом витрат на освіту Україна займає 57 місце із 153 країн світу. Проте цей показник дуже малий у порівнянні iз Кубою (12,9\%), Молдовою $(9,1 \%)$ та Данією $(8,7 \%)$. Незважаючи на це, Україна займає більш краще становище за якістю освіти. За рейтингом індексу рівня освіти між країнами світу наша держава займає 30 місце із індексом 0,796. У противагу їй Росія займає 36 місце із індексом якості освіти 0,780. Але всетаки більш якісну освіту здобувають в Австралії, що займає перше місце (індекс 0,927), США (індекс - 0,890), Німеччині (індекс - 0,884) та інших країнах.

Отже, фінансово-економічна криза $\epsilon$ шкідливим явищем, що згубно впливає на рівень дохідності населення України, його добробут, витрати, купівельну спроможність. На сучасному етапі кризового становища необхідно спрямувати всі дії на зупинення подальшого зниження рівня життя українців та утримувати його на базовому рівні. Для втримання та остаточного зупинення періоду кризи необхідна стабілізація сфери формування доходів населення. Це виконується за рахунок зменшення рівня інфляції та мінімізація рівня безробіття з боку втручання в економіку держави. Ще одним не менш вагомим фактором виступає національна грошова одиниця - гривня, що має мати стабільне положення по відношенню до іноземних валют; надання пільг для населення у повному обсязі та без затримок; збереження купівельної спроможності всіх соціальних пільг, а також рівня заробітної плати та пенсій, що вимагає корегування їх величини на рівень інфляції; підвищення рівня та удосконалення розробки державних соціальних стандартів i гарантій, установлення відповідної шкали оподаткування доходів населення [10].

Висновок. У статті досліджено напрями впливу фінансово-економічної кризи на доходи та витрати населення України, обгрунтовано іiі негативні наслідки, а також запропоновано основні шляхи їх вирішення. Вихід із фінансово-економічної кризи складний шлях, проте подолати його можливо. Задля стрімкого підвищення економіки країни в цілому кожен громадянин спочатку повинен поліпшити своє становище. Задля цього існує безліч можливостей. Одним iз шляхів покращення умов життя населення $\epsilon$ застосування кредитів. Цей метод забезпечує громадян коштами у потрібний для них період часу. Недоліком банківських кредитів $\epsilon$ повернення коштів із відсотками. Ця умова згоди не сильно вплине на доходи боржника через те, що сума сплати кредиту із відсотками розподіляється на частини, які, як правило, боржник у змозі буде повернути. У сфері кредитів також існує поняття споживчого кредиту, за допомогою якого громадяни України мають можливість купляти товари у розстрочку. На сучасному етапі політика магазинів спрямована на збільшення попиту та зосереджує у собі надання кредитів на товари без відсотків. Завдяки цьому населення у змозі отримати бажаний товар, не маючи на нього коштів. Також цей напрям економить час і гроші як споживача, так i продавця: споживач користується вже зараз та сплачує частинами, а продукція не залежується на полицях.

Ще одним напрямом збільшення своїх доходів населення може використовувати депозити - грошові вклади в банк на певний 
строк 3 умовою нарахування банком додаткових відсотків на рахунок вкладника за зберігання та використання цих коштів. Хоч депозити і заморожують кошти вкладника на певний строк, проте в кінці періоду він отримає додатковий прибуток. Також для примноження грошів у майбутньому можна варіювати національною валютою та іноземною. Наприклад, на відкладені кошти купити долар та продати його через певний час, коли він подорожчає. Це дасть змогу заробити на коштах, що звичайно просто лежать «під подушкою».

У зарубіжних країнах широко застосовують метод страхування. В європейських країнах, коли народжується дитина, ій відразу оформлюють накопичувальне страхування до весілля. За умовами цього методу страхова компанія у кінці строку виплачує повну суму всіх вкладень за весь період часу. За допомогою такого страхування можливо акумулювати певну суму коштів, якої вистачить на навчання у вищому навчальному закладі. Як і європейці, українці можуть забезпечити собі заможну старість застосовуючи накопичувальне страхування життя. Ще до пенсійного віку оформити такий договір i отримати велику суму при виході на пенсію. В Україні також $є$ різні види страхування i кожен може використовувати таку можливість. Ще одним напрямом незалежності від державних виплат та отримання високого доходу $\epsilon$ шлях підприємництва. Українська державна політика спрямована на підтримку нових бізнесменів та застосовує певні пільги: податкові канікули, зниження відсоткових ставок за кредитами та податками та інше. Ще одним ризиковим, але більш простішим способом отримання прибутків $є$ покупка акцій якого-небудь підприємства. Це дасть змогу власнику акцій одержувати відсотки за певний звітний період.

Отже, для покращення фінансового становища населення можливо застосовувати неоднорідні напрями, що забезпечують миттєве збільшення доходів громадян, або їх збільшення на перспективу.

\section{СПИСОК ЛІТЕРАТУРИ}

1. Arsenio M. Balisacan Tackling Poverty and Social Impacts: Philippine Response to the Global Economic Crisis / Arsenio M. Balisacan, Sharon Faye Piza, Dennis Mapa, Carlos Abad Santos, Donna Mae Odra. Pilipinas. - 2010.

2. Josef T. Yap Impact of the Global Financial and Economic Crisis on the Philippines / Josef T. Yap, Celia M. Reyes, Janet S. Cuenca. Pilipinas. -2009.

3. Malindi Myers The Impact of the Recession on Household Income, Expenditure and Saving // Office for National Statistics. - UK. $-2011$.

4. Sheria Myrie Effects of World Financial Crisis on Food Consumption Spending Among Households in Jamaica / Sheria Myrie, Oral Robinson // Developing Country Studies. Canada. - 2013.

5. Бандур C.I. Соціальний розвиток України: сучасні трансформації та перспективи / C.I. Бандур, Т.А. Заяць. Черкаси. - 2014. -С. 620.

6. Лук'яненко І.Г. Емпірична оцінка функції приватного споживання для України / I.Г. Лук'яненко, Г.Є. Могиляс // Наукові записки. Том 21, Економічні науки / Національний університет «КиєвоМогилянська академія». - 2013. - С. 3-10.

7. Державна служба статистики України. [Електронний ресурс]: - Режим доступу: http://www.ukrstat.gov.ua/

8. Національний банк України. [Електронний ресурс]: - Режим доступу: http://www.bank.gov.ua/

9. Головне управління статистики у харківській області. [Електронний ресурс]: Режим доступу: http://www.kh.ukrstat.gov.ua/

10.Чечель О. Пріоритетні засади формування національної концепції добробуту населення // Інвестиції: практика та досвід. - 2013. - №2. - с.87.

Рецензент д.е.н., професор ХНУ ім.В.Н. Каразіна Дорошенко О.Г. Експерт редакційної колегії к.е.н., доцент УкрДУЗТ Слагін Ю.В. 